\title{
Biology and use of the Pacific fat sleeper Dormitator latifrons (Richardson, 1844): state of the art review
}

\author{
Fernando Vega-Villasante ${ }^{1}(\mathbb{D})$, Luis E. Ruiz-González ${ }^{1}(\mathbb{D})$, Olimpia Chong-Carrillo ${ }^{1}$ \\ Mao E.R. Basto-Rosales ${ }^{2}$, David J. Palma-Cancino ${ }^{1}$ \\ Adrián Tintos-Gómez $^{3}{ }^{\mathbb{D}}$, Cynthia E. Montoya-Martínez ${ }^{1,7}$, Liza D. Kelly-Gutiérrez $^{1}$ \\ Saúl R. Guerrero-Galván ${ }^{1}$ (D) Jesús T. Ponce-Palafox ${ }^{4}(\mathbb{D})$, Ana Zapata ${ }^{1}$ \\ Gabriela E. Musin ${ }^{5}$ (D) Daniel Badillo-Zapata ${ }^{1,6}$ (D) \\ ${ }^{1}$ Laboratorio de Calidad de Agua y Acuicultura Experimental, Departamento de Ciencias Biológicas \\ Centro Universitario de la Costa, Universidad de Guadalajara, Puerto Vallarta, Jalisco, México \\ ${ }^{2}$ Tecnológico Nacional de Bahía de Banderas, La Cruz de Huanacaxtle, Bahía de Banderas, Nayarit, México \\ ${ }^{3}$ Centro de Investigaciones en Energías Renovables, Secretaría Técnica del Área Académica \\ Universidad Tecnológica de Manzanillo, Manzanillo, Colima, México \\ ${ }^{4}$ Escuela Nacional de Ingeniería Pesquera, Universidad Autónoma de Nayarit, San Blas, Nayarit, México \\ ${ }^{5}$ Instituto Nacional de Limnología (CONICET), Universidad Nacional del Litoral, Santa Fé, Argentina \\ ${ }^{6}$ Programa Cátedra CONACYT, Consejo Nacional de Ciencia y Tecnología \\ Ciudad de México, México. \\ ${ }^{7}$ Centro de Investigaciones Biológicas del Noroeste, S.C., La Paz, Baja California Sur, México \\ Corresponding author: Daniel Badillo-Zapata (danielbad00@hotmail.com)
}

\begin{abstract}
The present work is a review of the literature on the native Mexican fish Dormitator latifrons. The aim is to contribute to the integration and systematization of current knowledge to make it easier to identify existing knowledge gaps and breakthroghs Moreover, promote the successful cultivation and protection of this species whose consumption is increasing in Latin America. A review of the articles related to D. latifrons published in international and regional databases was carried out. The articles reviewed focus on taxonomy and systematics, phylogenetic, geographic distribution, ecology, physiology, reproduction, development, pathology, health, and the technologies used to cultivate this fish species. The conclusion is that, even though the cultivation of $D$. latifrons is of commercial interest in some countries, there are still significant gaps in our knowledge of biology and, consequently, the domestication potential of the species. Filling these gaps will require systematic research efforts on protecting natural populations and improving mass cultivation techniques.
\end{abstract}

Keywords: Dormitator latifrons; Eleotridae; native fish; ecology; culture; sustainable production

\section{INTRODUCTION}

The 2010 SOFIA (State of World Fisheries and Aquaculture) report by the Food and Agriculture Organization (FAO) showed clearly the impact on biodiversity and biosafety caused by the introduction of exotic species for purposes of aquaculture production (FAO 2010). Subsequent SOFIA reports (FAO 2012, 2014) no longer mentioned this problem, which was taken up again in 2016, but only at the European level, stating that invasive species are considered a serious threat to native biodiversity worldwide. The 2016 report also mentioned that only 50\% of the countries that practice aquaculture had implemented regulations to control the use of exotic species (FAO 2016). In Mexico, the study of native species with aquaculture potential has focused mainly on marine species, while continental aquaculture relies on

Corresponding editor: Leonardo Abitia 
exotic species such as tilapia and carp (Basto-Rosales et al. 2019). There are native freshwater species with high productive potential, but they have been poorly studied. One of these species is Dormitator latifrons.

Dormitator latifrons (Richardson, 1844), also called fat sleeper, chame, puyeque, popoyote, chococo, or chalaco, is a fish that has attracted biological interest for more than a hundred years (Castro-Rivera et al. 2005, Basto-Rosales et al. 2019). The first recorded study is by Eigenman \& Fordice (1885); however, since then, the amount of published information has been scarce, most of it about specific aspects of the ecology, physiology, and parasitology of the species (Todd 1973, 1975, Yáñez-Arancibia \& Díaz-González 1977, Chang \& Navas 1984, Lu et al. 1998, 2004, GarridoOlvera et al. 2004, Violante-González et al. 2008a,b, McDowall 2009).

In Ecuador, D. latifrons is considered a fishery and aquaculture resource (Arriaga \& Martínez 2003, Castro-Rivera et al. 2005, Schwarz 2007). That country has accumulated the greatest wealth of empirical knowledge on this species, as it is a key ingredient of traditional gastronomy and is cultivated from wild hatchlings. However, this empirical knowledge has not led to scientific publications, except for some undergraduate thesis and technical treatises that are not suitable for inclusion in this review. There are evident gaps in our knowledge about this species, hindering its management, conservation, reproduction in captivity, and cultivation.

The present review aims to systematize the existing scientific knowledge about this species to make evident the epistemological gaps that should be filled to efficiently manage wild populations of $D$. latifrons, conserve them, and cultivate them successfully.

\section{Taxonomy and phylogeny}

According to the integrated taxonomic information system (ITIS 2018), the taxonomy of this fish is as follows:

Phylum Chordata
Subphylum Vertebrata
Infraphylum Gnathostomata
Superclass Osteichthyes
Class Actinopterygii
Subclass Neopterygii
Infraclass Teleostei
Superorder Acanthopterygii
Order Perciformes
Suborder Gobioidei
Family Eleotridae

\author{
Genus Dormitator Gill, 1861 \\ Species Dormitator latifrons (Richardson, \\ 1844)
}

Eigenman \& Fordice (1885) made the first taxonomic description of the genus Dormitator. Common characteristics: body short and robust; head broad and flattened above; mouth slightly oblique, maxilla reaching the anterior margin of the orbit; lower jaw slightly projecting; vomer without teeth; large ctenoid scales; about 30 to 33 in longitudinal series; skull similar to Eleotris but wider. Dorsal fin VII-1,8; anal I, 9 or 10; preopercle spineless; post-temporal inserted midway between occipital crest and edge of skull; supraoccipital crest low. Some of the reported characteristics of $D$. latifrons include, among others, scales larger than in D. maculatus (Bloch, 1792), not much smaller on the belly; 18 scale series on the median line from the belly to the cloaca; 16 scale series on the midline from the posterior edge of the orbit to the front of the dorsal fin; the interspace between the dorsal fins less than the diameter of the orbit.

Kähsbauer (1973) described the pigmentation of the species as follows: dorsal area blue-green to green-red; bluish sidebands; skull slate-gray, ventral area bluish; belly pale gray; dorsal fin gray with black polka dots and red stripe; anal fin green on the base with dark spots on edge. The authors of this review found that field and laboratory observations report variations in the coloration of the integument, often caused by the color of the substrate on which they grow, ranging from deep brown-black on dark substrates to pale gray-green on light substrates such as those found in artificial reservoirs (Fig. 1).

The correct taxonomic placement of the species is controversial. Jordan \& Evermann (1898), and CastroAguirre (1978) indicated that the populations found on both sides of the American continent belong to the same species: Dormitator latifrons in the Pacific and Dormitator maculatus in the Gulf of Mexico (YáñezArancibia \& Díaz-González 1977). Other studies, including those by Miller (1966), Álvarez (1970), and Yáñez-Arancibia (1978), insist on the taxonomic validity of the species present in the Mexican Pacific. Uribe-Alcocer et al. $(1983,1989)$ compared karyotypes from gill epithelial tissue of $D$. latifrons and $D$. maculatus diploids; both species had similar karyotype features and chromosome structure. Based on the phylogenetic relationship of both species, the evolutionary trends of the Gobiidae family, and the cytogenetic features analyzed by the authors, UribeAlcocer et al. (1983) and Uribe-Alcocer \& RamírezEscamilla (1988) stated that the populations of the 


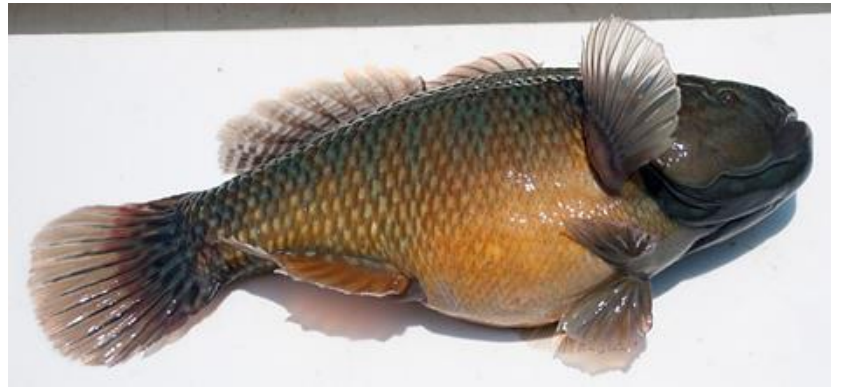

Figure 1. Adult male of Dormitator latifrons obtained from a culture in concrete ponds in Bahía de Banderas, Nayarit, Mexico.

genus Dormitator found on the Pacific and Gulf coasts should be considered a single species, given that they share an identical or extremely similar karyotype. Recent genetic research found the same sex chromosomes and other origin similarities between $D$. latifrons and the western Atlantic D. maculatus. The internal telomeric sequence suggests the heterochromosomes of the genus appear before one million years ago; the study also concludes that more research on chromosome localization of telomeric repeated sequences in other Dormitator and other Eleotrinae species is necessary to get a more comprehensive picture of the role of such sequences in the karyotype evolution of this group (Gomes-Paim et al. 2020). Furthermore, Galván-Quesada et al. (2016) demonstrated, through phylo-genetic analysis, that $D$. latifrons are the only species of the genus found in the Pacific Ocean. The authors note that the separation of this species from the other species in the genus occurred around one million years ago due to the closing of the Central American Isthmus and certain climatic and oceanographic changes.

\section{Distribution and ecology}

According to Kähsbauer (1973), Dormitator latifrons can be found in coastal lagoons, rivers, and streams of the Pacific slope, from California (USA) to Ecuador. However, members of this species have been reported down to Peru (Flores-Nava \& Brown 2010).

Dormitator latifrons is an omnivorous fish that feeds primarily on detritus, for which it is considered a primary consumer. Due to its trophic position, it competes interspecifically with other detritivorous fish, the most important of which are Mugil curema (Valenciennes, 1836), M. cephalus (Linnaeus, 1758), Gobionellus microdon (Gilbert, 1892), Eleotris picta (Kner, 1863) and Gobiomorus maculatus (Günther, 1859) (Yáñez-Arancibia \& Díaz -González 1977).
Dormitator latifrons belong to the group of diadromous fish, particularly to the group of amphidromous fish, together with 54 other species of Gobiidae. It spawns in freshwater bodies, the larvae migrate to the sea and then return to freshwater to spend the rest of their development (Milton 2009). Gobies species are usually born when in the early stages of embryonic development, surrounded by a large amount of yolk, which guarantees their survival and allows the larvae to be transported through streams and rivers to saltwater bodies (McDowall 2009). Todd (1975) indicates that after hatching, the larvae of $D$. latifrons, which lack neuromasts in the lateral line, direct their movements according to the perception of environmental conditions by different body structures, vertically moving following the concentration of oxygen, temperature, and salinity, looking for the best development conditions.

The peculiar physiological mechanisms that allow this species to adapt and survive have attracted the interest of numerous researchers. The presence of $D$. latifrons has been recorded in the macrofauna associated with the culture of Penaeus vannamei (Boone, 1931, Hendrickx et al. 1996). Sandoval-Huerta et al. (2014), conducted a study in four estuaries (Nexpa, Teolán, Mexcalhuacán and Barra de Pichi) in the Lázaro Cárdenas Municipality, Michoacán, Mexico. They collected 2014 specimens D. latifrons were the species with the highest abundance, 223 individuals, and the highest biomass, with 4,402 g. $D$. latifrons were also identified as the dominant species Mexcalhuachán and Barra de Pichi. Observations made by the authors of this work (unpubl. data) confirmed the presence of large, migratory (upstream) populations of $D$. latifrons in most rivers, streams, and pluvial drainage systems in the estuarine areas of Bahía de Banderas (Mexico), looking for freshwater environments, generally at the end of the rainy season (September-October). In general, the presence of $D$. latifrons in estuaries and coastal lagoons is common and abundant.

Warburton (1979) indicated that the recruitment of D. latifrons specimens occurred between February and April in the Huizáche-Caimanero Lagoon System (Sinaloa, Mexico), describing at least four cohorts with an average modal length of up to $19 \mathrm{~cm}$. NavarroRodríguez et al. (2010) studied the temporal-spatial variation in the distribution of the larvae of this species in the Boca Negra Estuary (Jalisco, Mexico). They suggested that their abundance is influenced by seasonal environmental variations (temperature, salinity), with the highest abundance in summer (rainy season) and the lowest in winter. 
The D. latifrons ability to thrive in different ecological niches makes it highly likely that it comes into contact with wastewater derived from various human activities, which would result in the accumulation of pollutants in fish tissues, as reported by Rodríguez et al. (2012). They found high levels of heavy metals, such as lead, chromium, cadmium, and manganese, in the gills and muscles of specimens collected in the Tres Palos Lagoon, in the state of Guerrero, Mexico. The same authors recommend a constant evaluation of the quality of the fish collected in this area since it is used as food by residents. There is no monitoring system for contaminants in food products from artisanal fishing in Mexico, and there is thus a high probability of consuming contaminated fish in various regions of the country.

\section{Reproduction}

Very little information has been published on the phenotypic differences in sexual development and growth between males and females of D. latifrons. These differences are not entirely clear, especially in juvenile stages. When close to sexual maturity, the males show a genital papilla, shaped in a triangle and colored pink to dark red. In females, the genital papilla color is a wine to brown, oval-shaped, and bordered by filaments (personal observations of the authors, Fig. 2). Vicuña (2010) indicates that signs of sexual maturation include the change of color in the genital papilla and abdomen, significant growth of the head in males, and significant abdominal bulging in females. Tresierra et al. (2002) described a maturation scale for males and females of this species, based on their gonadic development (Table 1).

Chang \& Navas (1984) mention that the reproduction of $D$. latifrons usually takes place in rivers and is influenced by a set of factors, including water levels, current strength, and salinity. Seasonal patterns of floods and droughts play a crucial role in this process; the largest amount of growth, the maturation of gonads, and the increase in the population of juveniles occur during the rainy season; however, the same authors mention that this species can reproduce throughout the year. Vicuña (2010) also mentions that the reproductive behavior of $D$. latifrons males is territorial and involves upward, circular movements around the female, while the female adopts a head-down position. The female releases oocytes, which adhere to the substrate, and are fertilized by the male with semen expelled through its genital papilla.

Rodríguez-Montes de Oca et al. (2012) conducted a study to obtain gametes and larvae of $D$. latifrons in the laboratory and determine the optimal reproduction conditions. They obtained favorable results regarding the induction of spawning and sperm release using salmon GnRHa and LHRHa. They also mentioned that the fertilization process and larvae hatching could occur with a salinity of $0-5$; hatching can also occur with a salinity of up to 15 . However, it has not been proved possible to produce larvae in stages that can be used as seeds for aquaculture, so further research is required to develop the technology that allows cultivating the species in captivity. It would also make it easier to conduct further studies of the species and yield several economic benefits.

\section{Eating habits and nutrition}

Yánez-Arancibia \& Díaz-González (1977) reported that the feeding habits of $D$. latifrons in the coastal lagoon system of the state of Guerrero, Mexico, are based on detritus and plant remains, corresponding to a primary consumer of the detritivorous type. However, depending on the time of the year, the place, and the availability of food, $D$. latifrons behave like primary consumers of the omnivorous type, adding to its diet annelids, copepods, other microfauna. The larvae of this species can start exogenous feeding on the fourth day after hatching, after consuming all the reserve yolk, and when the digestive tract and associated organs have fully developed. (López-López et al. 2015). The species has been described as having nocturnal feeding habits (Todd 1973). Observations carried out in pilot cultures established in concrete ponds suggest that feeding activity increases at sunset and continues until dawn (Basto-Rosales et al. 2019). However, the fish can be conditioned to feed at different times, even in the daytime.

Regarding the nutritional requirements of $D$. latifrons, no studies have produced enough information to determine what diet should be used for this species. Only one published study on the effect of various concentrations of proteins and lipids on the growth of juvenile specimens kept in captivity. That study concluded that a diet containing $30 \%$ proteins and $8 \%$ lipids was enough for ensuring a good development of these fish (Badillo-Zapata et al. 2018). Recently, Badillo-Zapata et al. (2021) experimented with partial and total substitution of fishmeal by soybean meal in juveniles feed; the results did not show negative effects in growth and apparent digestibility, suggesting the species absorbs an adequate amount of nutrients from vegetable sources.

\section{Physiology}

There are few published studies on the physiology of D. latifrons, and the studies that do exist focus on very specific topics, mainly hearing sensitivity. Lu et al. (1998) demonstrated that the response directionality of 


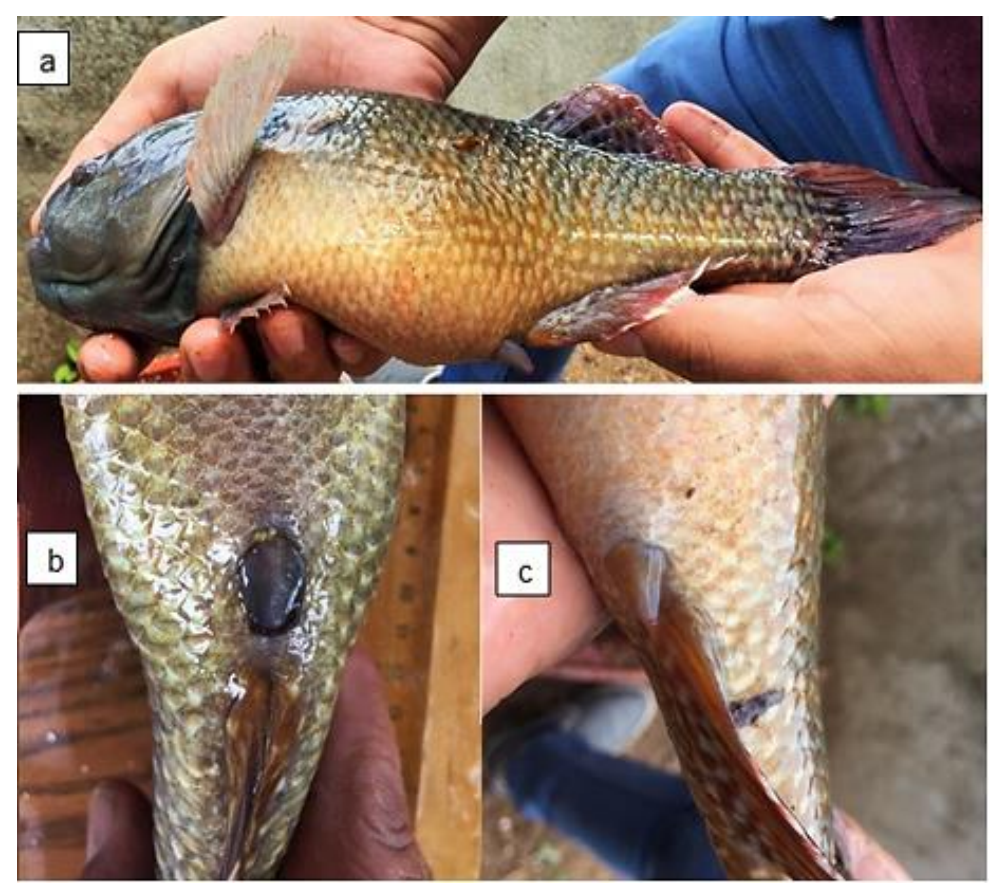

Figure 2. a) Mature male of Dormitator latifrons, with the characteristic coloration of the abdomen and protruded genital papilla. There are differences between the female and male genital papilla in D. latifrons, b) mature female genital papilla, c) mature male genital papilla.

a fish's auditory afferents is based on the morphological polarity of sensory hair cells in otolith organs. Lu \& Xu (2002) analyzed the effect of the unilateral and bilateral removal of saccular otoliths on the hearing sensitivity of $D$. latifrons and showed that the saccule plays an important role in directional hearing. Lu et al. (2003), studied the response of lagenar fibers and concluded that the lagena of $D$. latifrons plays a role in sound localization, particularly with high-intensity stimuli. The same authors studied the response properties of utricular fibers and concluded they play an auditory role and expand the dynamic range of the response in directional hearing ( $\mathrm{Lu}$ et al. 2004). Tomchik \& Lu (2005) studied octavolateral projections and organization in the medulla of the hindbrain of $D$. latifrons by making three-dimensional reconstructions of the cell nuclei and evaluating the overlap of the octavolateral projections; an important contribution to the knowledge of this structure in teleost fishes.

Regarding its respiratory capacity, Todd (1973) mentions that $D$. latifrons are organisms capable of surviving in waters with low oxygen concentrations and that, under totally anoxic conditions, they can rise to the surface and breathe air. However, this behavior has not been observed under laboratory conditions; under these conditions, with visual and auditory alterations, the fish avoided coming to the surface despite being exposed to hypoxia.
Chang (1984) conducted a study describing the resistance of $D$. latifrons to changes in salinity and outof-water exposure. He found that moving freshwater fish to water with 42 of salinity was fatal to $50 \%$ of the fish. However, in all cases in which the fish were moved from high-salinity water to zero-salinity water, the survival rate was $100 \%$. The fish exposed to air resisted $18 \mathrm{~h}$ without vegetation cover and almost $54 \mathrm{~h}$ with vegetation cover. Zapata et al. (2019) observed that fish transferred from freshwater to saltwater (15, 25 , and 33) reached basal levels of opercular movements (MO) (51 MO in freshwater) more rapidly. Opercular movements were how the stress produced by the change in salt concentration was recorded; this shows the osmoregulatory plasticity of this species and explains its distribution in both brackish and freshwater.

\section{Pathology and health}

Table 2 shows the list of parasites associated with $D$. latifrons. It can be seen that most of the studies have been carried out in the Tres Palos Lagoon, in the state of Guerrero, Mexico. According to Garrido-Olvera et al. (2004), intestinal parasites in this species are due to three factors: diet, feeding behavior, and vagility. The highest number of records in D. latifrons corresponds to parasites of the genus Gnathostoma (Owen, 1837) (Díaz et al. 2002, Martínez-Salazar \& León-Règagnon 
Table 1. The empirical scale of sexual maturity for females and males of Dormitator latifrons. Information consulted from Tresierra et al. (2002).

\begin{tabular}{|c|c|c|}
\hline Phase-state & Female & Male \\
\hline I. Virgin & $\begin{array}{l}\text { Small and transparent ovaries. The sex can be } \\
\text { recognized because the ovaries do not have } \\
\text { vesicles. }\end{array}$ & $\begin{array}{l}\text { The testicles are small and transparent. Sex is } \\
\text { distinguished based on the presence of } \\
\text { vesicles with the shape of folded leaves in the } \\
\text { extreme posterior third. }\end{array}$ \\
\hline II. Maturing virgin & $\begin{array}{l}\text { Small, light-colored ovaries. The ovules are not } \\
\text { visible to the naked eye. }\end{array}$ & $\begin{array}{l}\text { The testicles occupy half of the abdominal } \\
\text { cavity; their color is creamy. The vesicles are } \\
\text { the same width as the testes and can be seen } \\
\text { in the extreme posterior half of the testicles. }\end{array}$ \\
\hline III. In development & $\begin{array}{l}\text { The cylindrical ovaries occupy half of the } \\
\text { length of the abdominal cavity in terms of } \\
\text { length. They are opaque yellow. The ovules are } \\
\text { visible to the naked eye. }\end{array}$ & $\begin{array}{l}\text { The testicles occupy } 2 / 3 \text { of the abdominal } \\
\text { cavity and are of firm consistency, of creamy } \\
\text { color is with milky spots. The vesicles are } \\
\text { white and are wider than the testicles. }\end{array}$ \\
\hline IV. Developed & $\begin{array}{l}\text { With cylindrical ovaries that occupy } 2 / 3 \text { of the } \\
\text { abdominal cavity. Soft orange-yellow. The } \\
\text { blood supply is quite noticeable on the dorsal } \\
\text { side of the ovaries. The ovules are opaque } \\
\text { yellow in color and larger. }\end{array}$ & $\begin{array}{l}\text { The testicles are pearly cream in color, but } \\
\text { there is no milky flow when pressed. The } \\
\text { vesicles occupy } 2 / 3 \text { of the testicles. }\end{array}$ \\
\hline V. Gravid & $\begin{array}{l}\text { The ovaries occupy almost the entire } \\
\text { abdominal cavity and are orange-yellow. The } \\
\text { ovules are larger and yellow. At first glance, } \\
\text { there is a predominance of a single size of } \\
\text { ovules. }\end{array}$ & $\begin{array}{l}\text { The testicles are firm in consistency, } \\
\text { occupying almost the entire abdominal cavity. } \\
\text { They let out a milky flow when pressed. The } \\
\text { vesicles let out a viscous whitish liquid when } \\
\text { cut. }\end{array}$ \\
\hline VI. Spawning & $\begin{array}{l}\text { The ovaries occupy the entire abdominal } \\
\text { cavity, both in length and volume. The eggs are } \\
\text { light yellow, some of them translucent. The } \\
\text { genital opening is reddened. }\end{array}$ & $\begin{array}{l}\text { The testicles occupy the entire abdominal } \\
\text { cavity, are pearly milk in color, and let out a } \\
\text { milky flow when pressed. The vesicles are } \\
\text { highly developed. }\end{array}$ \\
\hline VII. After spawning & $\begin{array}{l}\text { The ovaries are flaccid with some ovules } \\
\text { inside. }\end{array}$ & $\begin{array}{l}\text { The testicles are somewhat flaccid, slightly } \\
\text { brown. The vesicles maintain their whitish } \\
\text { color and still let out the whitish liquid when } \\
\text { cut. }\end{array}$ \\
\hline VIII. Finished & $\begin{array}{l}\text { The ovules cannot be seen inside the ovaries, } \\
\text { which are reduced in size. }\end{array}$ & $\begin{array}{l}\text { The testicles are flattened, empty, do not let } \\
\text { out milk, and are dark brown. The vesicles are } \\
\text { reduced in size. }\end{array}$ \\
\hline
\end{tabular}

2005, García-Márquez 2005, Álvarez-Guerrero \& Alba-Hurtado 2007). Helminths of the genus Gnathostoma, housed in the gastrointestinal tract, certainly affect the fish host; their transfer to humans after consuming poorly cooked wild fish is considered a zoonosis and a public health problem (Vázquez et al. 2006). Some species of bacteria that have been identified as parasites in D. latifrons are Saccocoelioides lamothei (Aguirre-Macedo \& ViolanteGonzález 2008) in specimens collected in Tres Palos and Coyuca, and Neoechinorhynchus brentnickoli, (Monks et al. 2011) in organisms collected in three different regions of the Mexican Pacific (Tres Lagos Lagoon, Guerrero, Chamela Bay, Jalisco, Mazatlan, Sinaloa). Bacteria such as Vibrio sp., of public health interest, have also been isolated from wild D. latifrons specimens (Mendoza 2006), even though it has been shown that the mucus of this fish has a strong antimicrobial activity against the growth of different types of Gram-positive and Gram-negative bacteria, especially against strains of Vibrio vulnificus (Farmer, 1980) and V. harveyi (Baumann et al. 1981, Del Rosario et al. 2012)

Recent experimental cultures, with juveniles extracted from a natural environment, demonstrated the recurrent presence of ectoparasites in this fish species. These parasites could pose serious problems if the fish are kept in captivity in high densities. Vega-Villasante et al. (2017) reported a D. latifrons culture infested by the ectoparasite Argulus sp. (Müller, 1785) in Bahía de Banderas, in the state of Nayarit, Mexico; the prevalen- 
Table 2. Registry of parasites associated with Dormitator latifrons in different regions of Mexico.

\begin{tabular}{|c|c|c|}
\hline Species & Place & Reference \\
\hline Gnathostoma sp. (Owen, 1837) & Sinaloa, Mexico & Díaz et al. (2002) \\
\hline $\begin{array}{l}\text { Clinostomum complanatum (Rudolphi, 1819) } \\
\text { Pseudoacanthostomum panamense Caballero, Bravo- } \\
\text { Hollis \& Grocott, } 1953 \\
\text { Saccocoelioides sp. (Szidat, 1954) } \\
\text { Neoechinorhynchus golvani Salgado-Maldonado, } 1978 \\
\text { Contracaecum } \mathrm{sp} \text {. (Railliet \& Henry, 1912) } \\
\text { Cosmocerca podicipinus Baker \& Vaucher, } 1984\end{array}$ & Tres Palos Lagoon, Guerrero, Mexico & Garrido-Olvera et al. (2004) \\
\hline Gnathostoma binucleatum Almeyda-Artigas, 1991 & Amela Lagoon, Colima, Mexico & García-Mártquez (2005) \\
\hline Gnathostoma binucleatum & Tres Palos Lagoon, Guerrero, Mexico & $\begin{array}{l}\text { Martínez-Salazar \& León- } \\
\text { Règagnon (2005) }\end{array}$ \\
\hline Gnathostoma binucleatum & Laguna Agua Brava, Nayarit, Mexico & Álvarez \& Alba-Hurtado (2007) \\
\hline $\begin{array}{l}\text { Saccocoelioides lamothei Aguirre-Macedo \& Violante- } \\
\text { González, } 2008\end{array}$ & Guerrero, Mexico & $\begin{array}{l}\text { Aguirre-Macedo \& Violante- } \\
\text { González (2008) }\end{array}$ \\
\hline $\begin{array}{l}\text { Ascocotyle (Phagicola) longa Ransom, } 1920 \\
\text { Clinostomum complanatum } \\
\text { Contracaecum sp. } \\
\text { Echinochasmus leopoldinae Scholz, Ditrich, O. \& } \\
\text { Vargas-Vázquez, } 1996 \\
\text { Neoechinorhynchus golvani } \\
\text { Parvitaenia cochlearii Coil, } 1955 \\
\text { Pseudoacanthostomum panamense } \\
\text { Saccocoelioides sp. }\end{array}$ & Tres Palos Lagoon, Guerrero, Mexico & $\begin{array}{l}\text { Violante-González et al. } \\
\text { (2008a) }\end{array}$ \\
\hline $\begin{array}{l}\text { Ascocotyle (Phagicola) longa } \\
\text { Clinostomum complanatum } \\
\text { Contracaecum sp. } \\
\text { Echinochasmus leopoldinae } \\
\text { Neoechinorhynchus golvani } \\
\text { Parvitaenia cochlearii } \\
\text { Pseudoacanthostomum panamense } \\
\text { Saccocoelioides lamothei } \\
\text { Argulus sp. Müller, } 1785 \\
\text { Ergasilus } \text { sp. Von Nordmann, } 1832 \\
\end{array}$ & Tres Palos Lagoon, Guerrero, Mexico & $\begin{array}{l}\text { Violante-González et al. } \\
\text { (2008b) }\end{array}$ \\
\hline $\begin{array}{l}\text { Neoechinorhynchus brentnickoli Monks, Pulido-Flores } \\
\text { \& Violante-González, } 2011\end{array}$ & $\begin{array}{l}\text { Tres Palos Lagoon, Guerrero; } \\
\text { Chamela Bay, Jalisco; Mazatlán, } \\
\text { Sinaloa, Mexico }\end{array}$ & Monks et al. (2011) \\
\hline Argulus sp. & $\begin{array}{l}\text { La Cruz de Huanacaxtle, Nayarit, } \\
\text { Mexico }\end{array}$ & Vega-Villasante et al. (2017) \\
\hline
\end{tabular}

ce was $100 \%$ and the mortality reached $52 \%$ of the population.

Knowledge of the hematological parameters of a species is essential to determine its health status and its ability to cope with diseases caused by pathogens, environmental changes, or nutritional problems (Stoskopf 1993, Weiss \& Wardrop 2010). However, there is very little information on the hematology and blood chemistry of $D$. latifrons. The first assessment of some of these parameters was made by Todd (1972), who measured the concentration of erythrocytes $\left(3.2 \times 10^{6} \mathrm{~mm}^{3}\right)$ hematocrits $(39.1 \%)$, mean corpuscular volume (122.8 fL), hemoglobin concentration (15.5 $\mathrm{g} \%)$, mean corpuscular hemoglobin $(48 \mu \mu \mathrm{g})$ and mean corpuscular hemoglobin concentration (40.5\%) in organisms weighing between 150 and 350 g. RuizGonzález et al. (2020) calculated reference intervals and reported the following blood parameters for $D$. latifrons $(13 \pm 1$ and $43.1 \pm 6.9 \mathrm{~cm})$ : hematocrits $28 \%$, erythrocytes $2075 \times 106 \mathrm{~mm}^{3}$, leukocytes $35.035 \times 103$ $\mathrm{mm}^{3}$, VCM $161.54 \mathrm{fL}$, NTB 0.39 , glucose $51.467 \mathrm{mg}$ $\mathrm{dL}^{-1}$, protein $3.936 \mathrm{~g} \mathrm{dL}^{-1}$, albumin $1.906 \mathrm{~g} \mathrm{dL}^{-1}$, globulin $2.391 \mathrm{~g} \mathrm{dL}^{-1}$, and albumin/ globulin ratio 0.781 . These values correspond to benthic, sedentary, or slow-moving freshwater species (Larsson et al. 1976).

Ruiz-González et al. (2020) recorded a higher respiratory burst activity (a parameter that assesses the 
immune system's capacity through the oxidative activity of leukocytes) in $D$. latifrons compared to other species, which suggests that $D$. latifrons has a greater resistance to infections. The latter, together with the bactericidal effects of the integumentary mucus of this species, could explain its ability to thrive under conditions of high concentrations of organic residues, which promote the proliferation of macro and microorganisms, some of them with potential pathogenic capacity.

\section{Aquaculture}

Although D. latifrons has been classified as suitable for commercial cultivation (EcoCostas 2006), to date, no technology has been developed that allows to cultivate it without the need of obtaining seeds from wild populations, which is how it is currently done in countries such as Ecuador (Flores-Nava 2007) and Mexico (Basto-Rosales et al. 2019).

As said above, larval production under laboratory conditions continues to be a pending issue. Thus, this fish species cultivation depends on protecting its natural populations, subjected to anthropic pressures that have already begun to deplete them, as the authors of this work suggest. Although many studies, mostly from Ecuador, have focused on various aspects of the cultivation and feed of $D$. latifrons, they should be considered gray literature since they do not meet the quality and peer review requirements for including them in this review.

Florencio \& Serrano (1981) conducted one of the first studies on the cultivation of $D$. latifrons in the province of Manabí, Ecuador. They used natural reservoirs known as "ciénegas" for seeding organisms, taking advantage of the rainy season. The authors reported a maximum average weight of $722 \mathrm{~g}$ and a minimum average weight of 144 g. Chang \& Navas (1984) studied the growth of this fish in the Chone River basin (Ecuador) and reported that the highest growth rates were obtained with high water levels and low salinity (during the rainy season from January to April). They also reported seasonal changes in the gonads and a greater abundance of juveniles during the flood season. They estimated a yield of $115 \mathrm{~kg} \mathrm{ha}^{-1}$.

In recent years, Vicuña (2010) described various challenges and opportunities in the cultivation of $D$. latifrons, including the scarce or non-existent information on its specific nutritional requirements, its reproductive mechanisms, and its behavior in captivity. On the positive side, they note that $D$. latifrons have significant commercial potential due to their white, spineless meat, with high protein content. CastroRivera et al. (2005) evaluated the growth and fed conversion of males compared to females and the effect of feeding a mixed culture of these fish with a commercial feed containing $30 \%$ protein and $5 \%$ lipids. They reported very low growth, possibly due to the water temperature, which averaged $12^{\circ} \mathrm{C}$ during the 100 days of culture, not very appropriate for an eminently tropical fish. Cedeño (2013) evaluated the effects of feeding $D$. latifrons cultured in earthen ponds with algae (from the same natural substrate from which the fish were obtained), bovine manure dried under the sun, and a commercial balanced feed. The best growth values were obtained with the balanced feed, but the best performance (cost/weight gain) was obtained with bovine manure. Unfortunately, the author did not analyze the reasons for the effectiveness of bovine manure nor its nutritional value, and so possibly its most significant contribution was as a fertilizer of the pond substrate rather than as a highly nutritious feed. Agualsaca (2015) evaluated the growth of $D$. latifrons in 46-day cultures using natural detritus and balanced feed with $32 \%$ protein. The author reported that the fish fed with detritus grew slower than those fed with the balanced feed using feed rations equivalent to $4 \%$ of the total biomass, suggesting that detritus, although part of the diet of $D$. latifrons in nature, does not provide all the nutrients necessary for its optimal development.

Vega-Villasante et al. (2017) demonstrated the occurrence of the compensatory gain phenomenon in D. latifrons specimens, which showed an extraordinary increase in weight after receiving treatment against the ectoparasite Argulus sp. Once they reached a normal state of health and nutrition, the fish resumed growth, recovering their normal weight after two months. Basto-Rosales et al. (2019) evaluated the productive performance of this fish with four stocking densities (3, 5,6 , and 7 ind $\mathrm{m}^{-2}$ ) after 90 days. The results showed that there were no significant differences in productive performance between the different stocking densities.

\section{Food technology and nutritional information}

Even though D. latifrons is a food resource traditionally consumed in countries such as Ecuador and some other regions of the American Pacific coast, including some in Mexico, very little has been published on technological alternatives for its conservation or on its nutritional value.

Ganchoso et al. (2012) mixed beef with meat from D. latifrons to make sausages, evaluating three mixtures with different proportions of those ingredients. They concluded that the sausage with the least amount of fish meat (a ratio of 10:60, fish meat:beef) showed the best bromatological parameters. Regarding the nutritional value of the meat of $D$. latifrons, López-Huerta et al. (2018) determined the proximal composition and the fatty acid profile of wild 
and cultivated specimens of $D$. latifrons, intending to assess the effect of feeding cultured fish with a commercial diet for tilapia (Oreochromis spp.). The protein content of the muscle of wild fish was higher than that of farmed fish, but total lipid content was lower. The levels of fatty acids C18:1n9 and C18:2n6 were significantly higher $(P<0.05)$ in cultured fish, while the levels of C20:5n3 (EPA) and C22:6n3 (DHA) were significantly higher $(P<0.05)$ in wild fish. The $\mathrm{n} 3 / \mathrm{n} 6$ ratio was higher in wild fish.

Basto-Rosales et al. (2020) analyzed the amino acid profile of the muscle of D. latifrons and showed that it is similar to that of other fish of higher commercial value and that it meets the requirements for use as food for humans. These results show that the nutritional characteristics of $D$. latifrons can be beneficial for the nutrition of human beings, particularly for the communities within its distribution range.

\section{Dormitator latifrons in the Web of Science core collection}

The low number of articles on D. latifrons that show up in the Web of Science core collection shows how little studied this species has been. A query of article titles using the words "dormitator latifrons" across all the years included in the database until May 2021 yielded only 27 published articles. The first article was published in 1998; it was the only article published that year, as has been the case in most years since then, with or two records per year, except for the years with no publications at all, and the years 2008, and 2012, in which there were four and three published articles, respectively. Of the total number of articles (27), 25 are original articles, and 2 are scientific notes or short communications.

Mexico leads the production of articles published on this species, with $59 \%$ of the total, followed by USA with $29.6 \%$, Ecuador $18.5 \%$, and Cuba and Spain with only $3.7 \%$ each.

Regarding the institutions that have generated the articles, the Autonomous University of Guerrero and University of Guadalajara (Mexico) leads with five publications each, followed by the National Institute of Health (NIH), the National Institute of Environmental Health Sciences (NIEHS), the University of Miami, and the University of Sinaloa with four publications each. The most productive authors have been ViolanteGonzález, Badillo-Zapata and Vega-Villasante with five publications each; $\mathrm{Lu}$, with four publications and Aguirre-Macedo and $\mathrm{Xu}$, with three publications. There are 14 authors with two publications and five authors with only one publication on the subject.
The journals publishing the most about this species are the Journal of Comparative Physiology, and the Latin American Journal of Aquatic Research with four records. Ecosistemas and Recursos Agropecuarios, Revista de Biología Tropical and Journal of Fish Biology with two records. The rest of the journals (14) have only one record. Concerning the topics covered, the Web of Science shows that most of the publications have focused on zoology aspects, followed by fisheries, marine freshwater biology, neurosciences, behavioral sciences, parasitology, physiology biology, agriculture animal science and agriculture multidisciplinary

\section{CONCLUSIONS}

Dormitator latifrons is a native fish that has not been studied stably and continuously, so there are many important knowledge gaps regarding the basic and applied biology related to this species. There are no long-term population studies, and thus there is no information that could regulate its exploitation and that could serve to establish measures for its conservation. The physiology and ethology of $D$. latifrons are practically unknown, and therefore all attempts at captive management have been based and will be based on trial error. Only a few studies have focused on the technical requirements for the cultivation, the conservation of natural populations, the establishment of seed sources, or preserving the ecosystems inhabited by this species. More studies are needed on the abundance and distribution and its reproduction in captivity, genetics, and specific nutrition. Future studies must be conducted under scientific conditions and the results published in indexed journals since there is a large amount of gray literature with little or no editorial scrutiny that cannot be used as a reliable basis for further research.

\section{REFERENCES}

Agualsaca, O.J. 2015. Adaptación de chame (Dormitator latifrons) sometido a cautiverio utilizando cuatro niveles de detritus y balanceado en su alimentación. Tesis, Universidad de las Fuerzas Armadas-ESPE, Santo Domingo. [http://repositorio.espe.edu.ec/handle /21000/9692]. Reviewed: March 2, 2020.

Aguirre-Macedo, M. \& Violante-González, J. 2008. Saccocoelioides lamothei n. sp. from Dormitator latifrons (Pisces: Eleotridae) from coastal lagoons of Guerrero, México. Revista Mexicana de Biodiversidad, 79: 33-40. doi: 10.22201/ib.20078706e.2008. 001.509 
Álvarez, V.J. 1970. Peces mexicanos; claves. Secretaría de Industria y Comercio, Instituto Nacional de Investigación Pesquera, Ciudad de México.

Álvarez-Guerrero, G.C. \& Alba-Hurtado, F. 2007. Estuarine fish and turtles as intermediate and paratenic hosts of Gnathostoma binucleatum in Nayarit, Mexico. Parasitology Research, 102: 117-122. doi: 10.1007/s00436-007-0738-x

Arriaga, M.L. \& Martínez, O.J. 2003. Plan de ordenamiento de la pesca y acuicultura del Ecuador. Subsecretaría de Recursos Pesqueros, Guayaquil.

Badillo-Zapata, D., De Jesús, Z.F., Vega-Villasante, F., López-Huerta, J.M., Herrera-Resendiz, S., CuetoCortés, L. \& Guerrero-Galván, S.R. 2018. Requerimiento de proteína y lípidos para el crecimiento de juveniles del pez nativo Dormitator latifrons (Richardson, 1844). Ecosistemas y Recursos Agropecuarios, 5: 345-351. doi: 10.19136/era.a5n 14.1554

Badillo-Zapata, D., Musin, G., Palma-Cancino, D.J., Guerrero-Galván, S., Chong-Carrillo, O. \& VegaVillasante, F. 2021. Total or partial replacement of fishmeal with soybean meal in the diet of the Pacific fat sleeper (Dormitator latifrons) juveniles. Latin American Journal of Aquatic Research, 49: 40-47. doi: 10.3856/vol49-issue1-fulltext-2564

Basto-Rosales, M.E.R., Carrillo-Farnés, O., RodríguezMontes de Oca, G.A., Álvarez-González, C.A., Badillo-Zapata, D. \& Vega-Villasante, F. 2019. Growth of Dormitator latifrons under different densities in central Pacific coast of Mexico. Tropical and Subtropical Agroecosystems, 22: 489-493.

Basto-Rosales, M.E.R., Carrillo-Farnés, O., MontoyaMartínez, C.E., Badillo-Zapata, D., Rodríguez-Montes de Oca, G.A, Álvarez-González, C.A., et al. 2020. Meat protein quality of Dormitator latifrons (Pisces: Eleotridae): arguments for use by rural communities. Ecosistemas y Recursos Agropecuarios, 7: e2172. doi: 10.19136/era.a7n1.2172

Castro-Aguirre, J.L. 1978. Catálogo sistemático de los peces marinos que penetran a las aguas continentales de México con aspectos zoogeográficos y ecológicos. Dirección General del Instituto Nacional de Pesca, Serie Científica 19, Ciudad de Mexico.

Castro-Rivera, R., Aguilar, B.G. \& Hernández, G.J.P. 2005. Conversión alimenticia en engordas puras y mixtas de popoyote (Dormitator latifrons Richardson) en estanques de cemento. AquaTIC, 23: 45-52.

Cedeño, J.A. 2013. Alimentación del chame (Dormitator latifrons) con bovinaza y balanceado para mejorar la productividad. Investigación y Saberes, 2: 59-64.

Chang, B.D. 1984. Tolerances to salinity and air exposure of Dormitator latifrons (Pisces: Eleotridae). Revista de Biología Tropical, 32: 155-157.
Chang, B.D. \& Navas, W. 1984. Seasonal variations in growth, condition, and gonads of Dormitator latifrons (Richardson) in the Chone River Basin, Ecuador. Journal of Fish Biology, 24: 637-648. doi: 10.1111/ j.1095-8649.1984.tb04834.x

Del Rosario, M., De la Torre, H., Reyes, D., Noboa, A., Salazar, L., Marcillo, E. \& Muñoz, M. 2012. Presence of antimicrobial activity in the mucus of chame fish (Dormitator latifrons). Journal of Pure and Applied Microbiology, 6: 1615-1622.

Díaz, C.S., Willms, K., Zazueta, R.M., De La Cruz, O.M.C., Nawa, Y. \& Akahane, H. 2002. Morphology of Gnathostoma spp. isolated from natural hosts in Sinaloa, Mexico. Parasitology Research, 88: 639-645. doi: 10.1007/s00436-002-0636-1

EcoCostas. 2006. Estudio de factibilidad para la implementación de un centro de capacitación para el cultivo de chame (Dormitator latifrons) en el Estuario de Cojimíes. EcoCostas, Guayaquil.

Eigenman, C.H. \& Fordice, M.W. 1885. A review of the American Eleotridine. Proceedings of the Academy of Natural Sciences of Philadelphia, 37: 66-80. [https:// www.jstor.org/stable /4061092]. Reviewed: August 20, 2020.

Food and Agriculture Organization (FAO). 2010. The state of world fisheries and aquaculture 2010. FAO, Rome.

Food and Agriculture Organization (FAO). 2012. The state of world fisheries and aquaculture 2012. FAO, Rome.

Food and Agriculture Organization (FAO). 2014. The state of world fisheries and aquaculture 2014: opportunities and challenges. FAO, Rome.

Food and Agriculture Organization (FAO). 2016. The state of world fisheries and aquaculture 2016: contributing to food security and nutrition for all. FAO, Rome.

Florencio, A. \& Serrano, M. 1981. Algunos aspectos sobre la biología del chame, Dormitator latifrons. Revista de Ciencias del Mar y Limnología, 1: 73-82.

Flores-Nava, A. 2007. Aquaculture seed resources in Latin America: a regional synthesis. In: Assessment of freshwater fish seed resources for sustainable aquaculture. FAO, Rome.

Flores-Nava, A. \& Brown, A. 2010. Peces nativos de agua dulce de América del Sur de interés para la acuicultura: una síntesis del estado de desarrollo tecnológico de su cultivo. Serie Acuicultura en Latinoamérica de la FAO, Rome.

Galván-Quesada, S., Doadrio I.F., Alda, A., Perdices, R.G., Reina, M., Varela, G. \& DomínguezDomínguez, O. 2016. Molecular phylogeny and bio- 
geography of the amphidromous fish genus Dormitator Gill 1861 (Teleostei: Eleotridae). Plos One, 11: e0153538. doi: 10.1371/journal.pone.0153 538

Ganchoso, E.M.V., Mogue, C.D.J. \& Cusme, R.K.L. 2012. Optimización de combinación carne de chame (Dormitator latifrons) y carne de res en procesamiento de salchicha. EspamCiencia, 3: 147-154.

García-Márquez, L.J. 2005. Estudio de la gnatostomiasis en el estado de Colima, México. Tesis de Doctorado, Universidad de Colima, Manzanillo.

Garrido-Olvera, L., García-Prieto, L. \& Mendoza-Garfias, B. 2004. Helminth parasites of the Pacific fat sleeper, Dormitator latifrons (Richardson, 1844) (Osteichthyes: Eleotridae) from Tres Palos Lagoon, Guerrero, Mexico. American Midland Naturalist, 151: 165-169.

Gomes-Paim, F., Nirchio, M., Oliveira, C. \& Rossi, A.R. 2020. Sex chromosomes and internal telomeric sequences in Dormitator latifrons (Richardson 1844) (Eleotridae: Eleotrinae): an insight into their origin in the genus. Genes, 2020: 1-11. doi: 10.3390/genes110 60659

Hendrickx, M.E., Salgado-Barragán, J. \& Meda-Martínez, M.A. 1996. Abundance and diversity of macrofauna (fish and decapod crustaceans) in Penaeus vannamei culture ponds in Western Mexico. Aquaculture, 143: 61-73. doi: 10.1016/0044-8itis486(95)01233-8

Integrated Taxonomic Information System (ITIS). 2018. Standard report page: Dormitator latifrons. (n.d.). [https://www.itis.gov/servlet/SingleRptSingleRpt?sea rch_topic $=$ TSNysearch_value $=171918 \#$ null]. Reviewed: October 18, 2020.

Jordan, D.S. \& Evermann, B.W. 1898. The fishes of North and Middle America: a descriptive catalogue of the species of fish-like vertebrates found in the waters of North America, north of the Isthmus of Panama. Bulletin of the United States National Museum, New York. [https://repository.si.edu/handle/10088/30385]. Reviewed: March 2, 2020.

Kähsbauer, P. 1973. Über einige centralamerikanische Siluriden und Grobiiden. Annalen des Naturhistorischen Museums in Viena, 77: 263-273.

Larsson, A., Johansson-Sjöbeck, M.L. \& Fänge, R. 1976. Comparative study of some hematological and biochemical blood parameters in fishes from the Skagerrak. Journal of Fish Biology, 9: 425-440. doi: 10.1111/j.1095-8649.1976.tb04691.x

López-Huerta, J., Vega-Villasante, F., Viana, M.T., Carrillo-Farnés, O. \& Badillo-Zapata, D. 2018. First report of nutritional quality of the native fish Dormitator latifrons (Richardson, 1844) (Perciformes:
Eleotridae). Latin American Journal of Aquatic Research, 46: 849-854.

López-López, V.V., Rodríguez-Montes de Oca, G.A., Galavíz, M.A., Román-Reyes, C., Medina-Hernández, E.A., Dabrowski, K. \& Haws, M.C. 2015. Descripción histológica comparativa del desarrollo del sistema digestivo y visual de larvas de chame Dormitator latifrons (Pisces: Eleotridae). Latin American Journal of Aquatic Research, 43: 484-494.

Lu, Z. \& Xu, Z. 2002. Effects of saccular otolith removal on hearing sensitivity of the sleeper goby (Dormitator latifrons). Journal of Comparative Physiology A: Sensory, Neural, and Behavioral Physiology, 188: 595-602. doi: 10.1007/ s00359-002-0334-6

Lu, Z., Song, J. \& Popper, A.N. 1998. Encoding of acoustic directional information by saccular afferents of the sleeper goby, Dormitator latifrons. Journal of Comparative Physiology A: Sensory, Neural, and Behavioral Physiology, 182: 805-815.

Lu, Z., Xu, Z. \& Buchser, W.J. 2003. Acoustic response properties of lagenar nerve fibers in the sleeper goby, Dormitator latifrons. Journal of Comparative Physiology A: Sensory, Neural, and Behavioral Physiology, 189: 889-905. doi: 10.1007/s00359-003-0462-7

Lu, Z., Xu, Z. \& Buchser, W.J. 2004. Coding of acoustic particle motion by utricular fibers in the sleeper goby, Dormitator latifrons. Journal of Comparative Physiology A: Sensory, Neural, and Behavioral Physiology, 190: 923-938. doi: 10.1007/s00359-004-0550-3

Martínez-Salazar, E.A. \& León-Règagnon, V. 2005. Confirmation of Gnathostoma binucleatum (AlmeydaArtigas, 1991), advanced third-stage larvae in Tres Palos Lagoon, Mexico, by morphological and molecular data. Journal of Parasitology, 91: 962-965.

McDowall, R.M. 2009. Early hatch: a strategy for safe downstream larval transport in amphidromous gobies. Reviews in Fish Biology and Fisheries, 19: 1-8. doi: 10.1007/s11160-008-9085-y

Mendoza, R.R. 2006. Aislamiento de Vibrio sp. a partir de órganos internos de Dormitator latifrons (Richarson, 1844) silvestres: reporte preliminar. Revista Electrónica de Veterinaria, 7: 1695-7504.

Miller, R.R. 1966. Geographical distribution of Central American freshwater fishes. Copeia, 1966: 773-806.

Milton, D.A. 2009. Living in two worlds: diadromous fishes, and factors affecting population connectivity between tropical rivers and coasts. In: Nagelkerken, I. (Ed.). Ecological connectivity among tropical coastal ecosystems. Springer, Amsterdam.

Monks, S., Pulido-Flores, G. \& Violante-González, J. 2011. A new species of Neoechinorhynchus (Acanthocephala: Neoechinorhynchidae) in Dormitator lati- 
frons (Perciformes: Eleotridae) from the Pacific Coast of Mexico. Comparative Parasitology, 78: 21-28.

Navarro-Rodríguez, M.C., Flores-Vargas, R., GonzálezGuevara, L.F., Téllez-López, J. \& Amparán-Salido, R. 2010. Distribución y abundancia de las larvas de Dormitator latifrons (Pisces: Eleotridae) en el estero. Ciencia y Mar, 40: 3-9.

Rodríguez, A.R., Monks, S., Pulido, F.G., Gaytán, O.J.C., Romo, G.C. \& Violante, G.J. 2012. Metales pesados en el pez Dormitator latifrons (Richardson, 1884) y agua de la Laguna de Tres Palos, Guerrero, México. Ra Ximhai, 8: 43-47.

Rodríguez-Montes de Oca, G.A., Medina-Hernández, E., Velázquez-Sandoval, J., López-López, V.V., RománReyes, J.C., Dabrowski, K. \& Haws, M.C. 2012. Production of chame (Dormitator latifrons, Pisces: Eleotridae) larvae using GnRHa and LHRHa. Revista Colombiana de Ciencias Pecuarias, 25: 422-429.

Ruiz-González, L.E., Vega-Villasante, F., Tintos-Gómez, A., Del Rio-Zaragoza, O.B., Hernández-Rodríguez, M., Patiño, B.M. \& Badillo-Zapata, D. 2020. Some hematology and blood chemistry parameters of the Pacific fat sleeper Dormitator latifrons (Richardson, 1844). Latin American Journal of Aquatic Research, 48: 131-135. doi: 10.3856/vol48-issue1-fulltext-2343

Sandoval-Huerta, E.R., Madrigal-Guridi, X., EscaleraVázquez, L.H., Medina-Nava, M. \& DomínguezDomínguez, O. 2014. Estructura de la comunidad de peces en cuatro estuarios del Pacífico mexicano central. Revista Mexicana de Biodiversidad, 85: 11841196.

Schwarz, L. 2007. Freshwater fish seed resources in Ecuador. In: Bondad-Reantaso, M.G. (Ed.). Assessment of freshwater fish seed resources for sustainable aquaculture. FAO, Rome, pp. 233-240.

Stoskopf, M. 1993. Fish medicine. W.B. Saunders Company, Philadelphia.

Todd, E.S. 1972. Hemoglobin concentration in a new airbreathing fish. Journal of Comparative Physiology A: Sensory, Neural, and Behavioral Phy-siology, 42: 569573.

Todd, E.S. 1973. Positive buoyancy and air-breathing: a new piscine gas bladder function. Copeia, 1973: 461464.

Todd, E.S. 1975. Vertical movements and development of the prolarvae of the eleotrid fish, Dormitator latifrons. Copeia, 1975: 564-568.

Tomchik, S.M. \& Lu, Z. 2005. Octavolateral projections and organization in the medulla of a teleost fish, the sleeper goby (Dormitator latifrons). Journal of Com- parative Physiology A: Sensory, Neural, and Behavioral Physiology, 481: 96-117.

Tresierra, A., Culquichicon, Z. \& Veneros, B. 2002. Biología reproductiva en peces. Editorial Nuevo Norte, Trujillo.

Uribe-Alcocer, M. \& Ramírez-Escamilla, A. 1989. Comparación citogenética entre las especies del género Dormitator (Pisces: Gobiidae). Anales del Instituto de Ciencias del Mar y Limnología, 16: 75-80.

Uribe-Alcocer, M., Arreguín-Espinosa, J., Torres-Padilla, A. \& Castro-Pérez, A. 1983. Los cromosomas de Dormitator latifrons (Pisces: Gobiidae). Anales del Instituto de Ciencias del Mar y Limnología, 10: 23-30.

Vázquez, T.O., Campos, R.T. \& Rondán, Z.A. 2006. Gnatostomiasis humana: abordaje, diagnóstico y tratamiento. Revista del Centro de Investigación de La Universidad La Salle, 7: 65-76.

Vega-Villasante, F., Cueto-Cortés, L., Basto-Rosales, M.E.R., Badillo-Zapata, D., Chong-Carrillo, O., RuizGonzález, L.E. \& Montoya-Martínez, C.E. 2017. Presencia de Argulus sp. en un cultivo de Dormitator latifrons: prevalencia, mortalidad y tratamiento. Revista Bio Ciencias, 4: 1-14. doi: 10.15741/revbio. 04.06.05

Vicuña, O. 2010. Peces nativos de agua dulce de América del Sur de interés para la acuicultura: una síntesis del estado de desarrollo tecnológico de su cultivo. Serie acuicultura en Latinoamérica. FAO, Rome.

Violante-González, J., Aguirre-Macedo, M.L. \& VidalMartínez, V.M. 2008a. Temporal variation in the helminth parasite communities of the Pacific fat sleeper, Dormitator latifrons, from Tres Palos Lagoon, Guerrero, Mexico. Journal of Parasitology, 94: 326334. doi: 10.1645/GE-1251.1

Violante-González, J., Rojas-Herrera, A. \& AguirreMacedo, L.M. 2008b. Seasonal patterns in metazoan parasite community of the "fat sleeper" Dormitator latifrons (Pisces: Eleotridae) from Tres Palos Lagoon, Guerrero, Mexico. Revista de Biología Tropical, 56: 1419-1427.

Weiss, D.J. \& Wardrop, K.J. 2010. Schalm's veterinary hematology. Wiley-Blackwell Publishing, New Jersey.

Warburton, K. 1979. Growth and production of some important species of fish in a Mexican coastal lagoon system. Journal of Fish Biology, 14: 449-464. doi: 10.1111/j.1095-8649.1979.tb03542.x

Yáñez-Arancibia, A. 1978. Taxonomía, ecología y estructura de las comunidades de peces en lagunas costeras con bocas efímeras del Pacífico de México. Centro de Ciencias Del Mar y Limnología, Univer- 
sidad Nacional Autónoma de México, Ciudad de México.

Yáñez-Arancibia, A. \& Díaz-González, G. 1977. Trophicdynamic ecology of Dormitator latifrons (Richardson) in nine coastal lagoons on the Pacific coast of Mexico. (Pisces: Electridae). Instituto de Ciencia del Mar y Limnología, 19: 140.

Received: September 28, 2020; Accepted: January 82021
Zapata, A.A., Vega-Villasante, F., Chong-Carrillo, O., Vargas-Ceballos, M.A. \& Badillo-Zapata, D. 2019. Efecto de la salinidad sobre la frecuencia ventilatoria branquial de Dormitator latifrons (Richardson, 1984). Ecosistemas y Recursos Agropecuarios, 6: 601-607. doi: 10.19136/era.a6n18.2179 